\title{
Cisinta
}

International Joựnat: of Information System: $\&$ Téchino

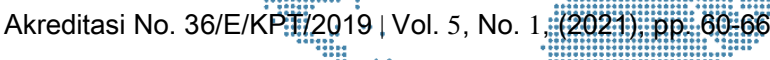

\section{Decision Making on Student Academic Achievement Assessment Using the Topsis Method}

\author{
Susliansyah ${ }^{1}$, Aditia Dwinanto ${ }^{2}$, Heny Sumarno $^{3}$, Hendro: Priyono ${ }^{4}$, Linda \\ Maulida ${ }^{5}$
}

Universitas Bina Sarana Informatika

susliansyah.slx@bsi.ac.id,Adityadwinanto@gmail.com,heny_nyno@yahoo.com, hendrop250@gmail.com,linda.lma@bsi.ac.id

\begin{abstract}
Student academic achievement is a very important matter for all school parties that are directly or indirectly related, especially for Depok Tourism Vocational School, student academic achievement is one of the benchmarks in the success of education. Currently, the process of determining student achievement from the academic side of the Depok Tourism Vocational School is still using a manual system, so it takes a long time to determine the assessment of student academic achievement, because there are quite a lot of student data recording. In addition, it is still less relevant because it has not used the right calculation method, resulting in inaccurate calculations. This research uses the Technique For Order Preference by Similarity to Ideal Solution (TOPSIS) method, because this method is a simple concept and easy to understand and to help the optimal decision-making process to solve practical decision problems. The results of the research using the Technique For Order Preference by Similarity to Ideal Solution (TOPSIS) method found that students with the name Akmal Adnanto got the first rank with the highest preference value of 0.760 .
\end{abstract}

Keywords: Decision Support System, Technique For Order Preference by Similarity to Ideal Solution (TOPSIS), Student Academic Achievements.

\section{Introduction}

The concept of a Decision Support System (DSS) was first put forward in the early 1970s by Michael S. Scott Morton with the term Management Decision System. The system is a computer-based system that is intended to assist decision makers [1] by utilizing certain data and models to solve various semi-structured problems [2]. TOPSIS is a multi-criteria decision-making method [3] or alternative choice which is an alternative that has the smallest distance from the positive ideal solution and the largest distance from the negative ideal solution from a geometric point of view using Euclidean distance. However, the alternative that has the smallest distance from the positive ideal solution, does not have to have the largest distance from the negative ideal solution [4].. People who excel have a very large development of science and knowledge. However, choosing a school can also affect education in exploring the achievements to be achieved [5]. Learning achievement in the field of education is the result of measurements of students which include cognitive, affective and psychomotor factors after participating in the learning process which is measured using test instruments or relevant instruments [6]. Currently, the process of determining student academic achievement at the Depok Tourism Vocational School is still applying a manual system [7] with several obstacles and tends to [8] requires a long time [9] in determining student achievement. This is because in recording student data it is only seen from the average value of report cards [10], besides that in determining student academic achievement it is still less relevant because it has not used an inaccurate calculation method [11], so it has an impact on calculations that become inaccurate. 


\section{Research and Methodology}

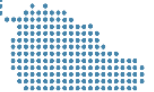

Activities in the methodology that will be carried out in the process of researeh statges include:

\subsection{Data Collection Activities}

In the process of collecting data, activities use two ways, including:"

a. Primary data: Research data collection is done by coming directly to the Depok Tourism Vocational School, aiming to find out data related to academic achievement assessments that are carried out every semester.

b. Secondary data: Retrieval of research data by obtaining from sources such as books, journals, seminars and articles, aims to strengthen the resolution of research problems.

\subsection{Data Analysis Activities}

In the activity process in conducting data analysis, then the data that has been obtained will be analyzed to meet the needs in the calculation process using the TOPSIS method which is used if the conclusions obtained can be proven by numbers and also in calculations.

\subsection{Data Processing Activities}

After the data analysis activity is complete, then the data will be processed using several steps, including:

a. Determining Criteria and Alternative Data.

1). Data criteria that will be used in the assessment of student academic achievement such as: the average value of report cards, behavior scores, activity values and attendance.

2). Alternative data that will be used in the assessment of student academic achievement that will be used as research data are only data for class X students, data for class XI students and data for class XII students. From all classes, 6 students were taken randomly.

b. Performing Calculations Using the TOPSIS Method

1) Step 1: Normalize the alternatives

2) Step 2: Assign values, create a Weights table.

3) Step 3: Weight each criterion

4) Step 4: Making a normalized decision normalized formula:

$$
\mathrm{R}_{11}=\frac{\mathrm{X}_{11}}{\sqrt{\mathrm{X}_{11}{ }^{2}+\mathrm{X}_{21}{ }^{2}+\mathrm{X}_{31}{ }^{2}+\mathrm{X}_{41}{ }^{2}+\mathrm{X}_{51}{ }^{2}+\mathrm{X}_{61}{ }^{2}+\mathrm{X}_{71}{ }^{2}+\mathrm{X}_{81}{ }^{2}+\mathrm{X}_{91}{ }^{2}+\mathrm{X}_{101}{ }^{2}+\cdots \cdot \mathrm{n}}}
$$

5) Step 5: Creating a Weighted Normalization

Formula:

$$
\mathrm{Vij}=\text { wi. .rij }
$$

6) Step 6: Finding Max and Min of Weighted Normalization

Formula:

$$
\begin{aligned}
& A^{+}=\left(y 1^{+}, y 2^{+} \ldots . y n^{+}\right. \\
& A^{-}=\left(y 1^{-}, y 2^{-} \ldots . . y n^{-}\right.
\end{aligned}
$$

7) Step 7: Look for D+ D- in each Alternative

Formula:

$$
\begin{gathered}
D_{i}^{+}=\sqrt{\sum_{j}^{n}=1\left(y_{i j}-y_{j}^{+}\right)^{2}} \\
D_{i}^{-}=\sqrt{\sum_{j}^{n}=1\left(y_{i j}-y_{j}^{-}\right)^{2}}
\end{gathered}
$$




\section{asinta}

8) Step 8 : Finding V/Result Formula:

$$
V_{i}=\frac{D_{i}^{-}}{D_{i}^{-}+D_{i}^{+}}
$$

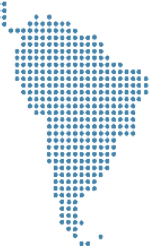

\section{Results and Discussion}

Solving problems with the TOPSIS method can be done by looking at the criteria that have been set, namely the average value of report cards, behavior values, activity values and attendance. These criteria are considered as criteria that are used as factors to determine student academic achievement. The steps for the Technique For Order Preference by Similarity to Ideal Solution (TOPSIS) method are as follows:

\subsection{Determining the value relative to each alternative}

Table 1. Alternative values for each criterion

\begin{tabular}{|l|l|l|l|l|l|}
\hline No & Name & $\begin{array}{l}\text { Value } \\
\text { Average } \\
\text { Report }\end{array}$ & $\begin{array}{l}\text { Value } \\
\text { Behavior }\end{array}$ & $\begin{array}{l}\text { Value } \\
\text { Activity }\end{array}$ & $\begin{array}{l}\text { Value Total } \\
\text { Attendance }\end{array}$ \\
\hline 1 & Achmad Rafi Saputra & 80 & 80 & 60 & 156 \\
\hline 2 & Adam Tirtayasa & 82 & 80 & 80 & 153 \\
\hline 3 & Ahmad Bukhori & 80 & 80 & 80 & 140 \\
\hline 4 & Ahmad Imron Rosadi & 81 & 75 & 79 & 151 \\
\hline 5 & Akmal Adnanto & 81 & 90 & 85 & 156 \\
\hline 6 & Ali Fajar Wahidin & 77 & 100 & 78 & 130 \\
\hline
\end{tabular}

The table above is an explanation of the normalized sample data of students from class X, XI, II.

Table 2. Assessment Criteria

\begin{tabular}{|l|l|}
\hline Sub Aspect & Criteria \\
\hline Value Average Report & $\mathrm{C} 1$ \\
\hline Value Behavior & $\mathrm{C} 2$ \\
\hline Value Activity & $\mathrm{C} 3$ \\
\hline Value Total Attendance & $\mathrm{C} 4$ \\
\hline
\end{tabular}

The table above is an explanation of the existing criteria in SMK, where these criteria will be used as a reference for calculating student academic achievement assessments every semester.

\subsection{Creating a Weighted Table.}

Table 3. Weight Criteria

\begin{tabular}{|l|l|}
\hline Predicate & $\begin{array}{l}\text { Weight } \\
\text { Interest }\end{array}$ \\
\hline Very Important & $30 \%$ \\
\hline Important & $25 \%$ \\
\hline Enough & $20 \%$ \\
\hline Not Important & $15 \%$ \\
\hline Very Unimportant & $10 \%$ \\
\hline
\end{tabular}

The table above is an explanation of the weight value criteria that function to be able to measure the predetermined criteria, where the total value of the weight criteria is $100 \%$ 


\subsection{Weighting Each Criterion.}

Table 4. Value of Weight

\begin{tabular}{|l|l|l|l|}
\hline Sub Aspect & Criteria & Description & $\begin{array}{l}\text { Value } \\
\text { Weight }\end{array}$ \\
\hline Value Average Report & C1 & Very Important & $30 \%$ \\
\hline Value Behavior & C2 & Important & $25 \%$ \\
\hline Value Activity & C3 & Enough & $20 \%$ \\
\hline Value Total Attendance & C4 & Important & $25 \%$ \\
\hline
\end{tabular}

The table above is an explanation of the criteria that have been given a weighted value of importance in order to know the difference in the level of importance of each criterion, where the total value of the criteria is $100 \%$

\subsection{Creating a normalized decision matrix.}

At this stage, to simplify the calculation process, where the calculation is done by finding the square root of the value of each criterion.

The calculation of the normalized decision matrix on the criteria for the Average Scorecard (C1) is:

$$
|X 1| \sqrt{\begin{array}{c}
(80)^{2}+(82)^{2}+(80)^{2}+ \\
(81)^{2}+(81)^{2}+(77)^{2} \\
=196,405
\end{array}}
$$

In the search, it can be obtained from the value of each alternative that is on the criteria for the average value of report cards $(\mathrm{C} 1)$ divided by the results of the cube roots that have been obtained for the criteria for the average value of report cards $(\mathrm{C} 1)$. Then the value of 80 is obtained from Alternative 1 on the $\mathrm{C} 1$ criteria (average value) and the value of 196.405 is the result of the square root of Alternatives 1 to 6 .

$\mathrm{R}(1.1)=80 / 196.405=0.407$

$\mathrm{R}(2.1)=82 / 196.405=0.418$

$\mathrm{R}(3.1)=80 / 196.405=0.407$

$\mathrm{R}(4.1)=81 / 196.405=0.412$

$\mathrm{R}(5.1)=81 / 196.405=0.412$

$\mathrm{R}(6.1)=77 / 196.405=0.392$

Table 5. Normalized Matrix Data

\begin{tabular}{|l|l|l|l|l|l|}
\hline No & Student Name & C1 & C2 & C3 & C4 \\
\hline 1 & Achmad Rafi Saputra & 0.407 & 0.386 & 0.316 & 0.430 \\
\hline 2 & Adam Tirtayasa & 0.418 & 0.386 & 0.422 & 0.422 \\
\hline 3 & Ahmad Bukhori & 0.407 & 0.386 & 0.422 & 0.386 \\
\hline 4 & Ahmad Imron Rosadi & 0.412 & 0.362 & 0.417 & 0.417 \\
\hline 5 & Akmal Adnanto & 0.412 & 0.434 & 0.448 & 0.430 \\
\hline 6 & Ali Fajar Wahidin & 0.392 & 0.483 & 0.411 & 0.359 \\
\hline
\end{tabular}

\subsection{Create a weighted normalized decision matrix}

At this stage, each alternative is taken based on the value of the weight value criteria multiplied by the normalization result criteria.

The calculation of the V Weighted Normalized Decision Matrix on the criteria for the average value of report cards $(\mathrm{C} 1)$ is: 


\section{A sinta}

The search for normalized calculations weighted V on the weightessef the criteriater the average value of report cards $(\mathrm{C} 1)$ is $0.3(30 \%)$, that is, with the description of criteria being very important, and alternative 1 on the criteria forthe average tatue of report cards $(\mathrm{C} 1)$ is 0.407 . The results of the $\mathrm{C} 1$ normalized decision calculation and so on until the last alternative calculation can be seen below.

$\mathrm{V} 1.1=\mathrm{W} 1 \times \mathrm{R} 1.1=0.122$

$\mathrm{V} 2.1=\mathrm{W} 1 \times \mathrm{R} 2.1=0.125$

$\mathrm{V} 3.1=\mathrm{W} 1 \times \mathrm{R} 3.1=0.122$

$\mathrm{V} 4.1=\mathrm{W} 1 \times \mathrm{R} 4.1=0.124$

$\mathrm{V} 5.1=\mathrm{W} 1 \times \mathrm{R} 5.1=0.124$

$\mathrm{V} 6.1=\mathrm{W} 1 \times \mathrm{R} 6.1=0.118$

Table 6. Weighted Normalized Matrix $\mathrm{V}$

\begin{tabular}{|l|l|l|l|l|}
\hline No & C1 & C2 & C3 & C4 \\
\hline 1 & 0.122 & 0.097 & 0.063 & 0.108 \\
\hline 2 & 0.125 & 0.097 & 0.084 & 0.106 \\
\hline 3 & 0.122 & 0.097 & 0.084 & 0.097 \\
\hline 4 & 0.124 & 0.091 & 0.083 & 0.104 \\
\hline 5 & 0.124 & 0.109 & 0.090 & 0.108 \\
\hline 6 & 0.118 & 0.121 & 0.082 & 0.090 \\
\hline
\end{tabular}

\subsection{Finding Max and Min of Weighted Normalization}

Searching for max values (positive ideal solution) and min (negative ideal solution) on each criterion from alternatives 1 to 6 , the results are shown in the table below.

Table 7. Positive Ideal Solution and Negative Ideal Solution

\begin{tabular}{|l|l|l|l|l|}
\hline Ideal Solution & C1 & C2 & C3 & C4 \\
\hline A+ & 0.125 & 0.121 & 0.090 & 0.108 \\
\hline A- & 0.118 & 0.091 & 0.063 & 0.090 \\
\hline
\end{tabular}

\subsection{Finding D+ D- in each Alternative}

A. Weighted calculation Positive Ideal Solution D+

Values of $0.125,0.121,0.090$ and 0.108 were obtained from positive ideal results $(\mathrm{A}+)$ on criteria $\mathrm{C} 1, \mathrm{C} 2, \mathrm{C} 3$ and $\mathrm{C} 4$ and values of $0.122,0.097,0.063$ and 0.108 were values obtained from the weighted normalized calculation results in alternative 1 in the critical

$$
D_{1}^{+}=\sqrt{\begin{array}{l}
(0,125-0,122)+ \\
(0,121-0,097)+ \\
(0,090-0,063)+ \\
(0,108-0,108)+
\end{array}}=0,036
$$

B. Weighted Calculation of Negative Ideal Solution D-

Values of $0.118,0.091,0.063$ and 0.090 were obtained from positive ideal results (A-) on criteria $\mathrm{C} 1, \mathrm{C} 2, \mathrm{C} 3$ and $\mathrm{C} 4$ and values of $0.122,0.097,0.063$ and 0.108 were values obtained from the weighted normalized calculation results in alternative 1 in criteria $\mathrm{C} 1$, $\mathrm{C} 2, \mathrm{C} 3$ and $\mathrm{C} 4$.

Table 8. Weighted Calculation of D+ and D-

\begin{tabular}{|l|l|l|l|}
\hline No & Student Name & $\mathbf{D}^{+}$ & $\mathbf{D}^{-}$ \\
\hline 1 & Achmad Rafi Saputra & 0.036 & 0.019 \\
\hline 2 & Adam Tirtayasa & 0.025 & 0.028 \\
\hline 3 & Ahmad Bukhori & 0.027 & 0.023 \\
\hline 4 & Ahmad Imron Rosadi & 0.031 & 0.025 \\
\hline
\end{tabular}




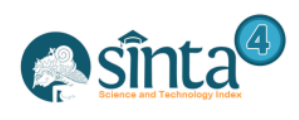

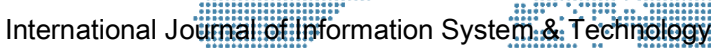

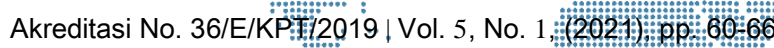

\begin{tabular}{|c|c|c|c|}
\hline No & Student Name & $\mathbf{D}^{+}$ & D \\
\hline 5 & Akmal Adnanto & 0.012 & 0.038 \\
\hline 6 & Ali Fajar Wahidin & 0.021 & $0.03 \frac{6}{6}$ \\
\hline
\end{tabular}

:

The table above is the result of the calculation of alternative 1 to alternative 6 for the values (D+) and (D-).

\subsection{Finding the Preference Values for the Results of Each Alternative (Vi )}

At the stage to find the value of $\mathrm{V}$ is the alternative distance $\mathrm{Ai}$ with a negative ideal solution divided by the alternative distance Ai with a negative ideal solution plus the alternative distance $\mathrm{Ai}$ with a positive ideal solution.

Calculation of preference value for each alternative $(\mathrm{Vi})$

The value of 0.019 is the value in alternative 1 obtained from the negative ideal weighted result (D-) and the value of 0.036 from the positive weighted result (D+).

$V_{1}=\frac{0,019}{0,019+0,036}=\frac{0,019}{0,055}=0,345$

The calculation results obtained above are the final results that have been carried out at all stages from alternative 1 to alternative 6 .

Table 9. Preference Values For Each Alternative (Vi)

\begin{tabular}{|l|l|l|}
\hline No & Nama Siswa & $\left(\mathbf{V}_{\mathbf{i}}\right)$ \\
\hline 1 & Achmad Rafi Saputra & 0.345 \\
\hline 2 & Adam Tirtayasa & 0.528 \\
\hline 3 & Ahmad Bukhori & 0.460 \\
\hline 4 & Ahmad Imron Rosadi & 0.446 \\
\hline 5 & Akmal Adnanto & 0.760 \\
\hline 6 & Ali Fajar Wahidin & 0.632 \\
\hline
\end{tabular}

\section{Conclusion}

The research was conducted using criteria such as the average value of report cards, behavior values, activity values and attendance numbers using the Technique For Order Preference by Similarity to Ideal Solution (TOPSIS) method, then the student who had the highest score named Akmal Adnanto with a preference value of 0.760 .

\section{References}

[1] N. Andriyani and A. Hafiz, "Perbandingan Metode AHP dan Topsis dalam Penentuan Siswa Berprestasi," in Seminar Nasional Teknologi Dan Bisnis 2018, 2018, pp. 362-371.

[2] Warjiyono, "Sistem Pendukung Keputusan Untuk Mengetahui Bakat Akademik Anak Menggunakan Metode Topsis," Inf. Syst. Educ. Prof., vol. 1, no. 1, pp. 1-8, 2016.

[3] M. S. Munir, M. M. Nizam, and R. Parlika, "Implementasi Metode Topsis ( Technique For Order Of Preferance By Similarity To Ideal Solution ) Untuk Penentuan Siswa Terbaik Preference by Similarity to Ideal Adapun yang menjadi batasan masalahnya," SCAN, vol. XI, no. 2, pp. 41-46, 2016.

[4] N. Rahmadani, "Sistem pendukung keputusan untuk menentukan mahasiswa lulusan terbaik dengan metode topsis," in Seminar Nasional Royal, 2018, pp. 289294.

[5] M. Muslihudin and D. Rahayu, "Sistem Pendukung Keputusan Siswa Berprestasi Menggunakan Metode Weighted Product," TAM (Technology Accept. Model., vol. 9, no. 2, pp. 114-119, 2018. 
[6] A. A. . P. Ardyanti, N. Purnama, and N. L. Nyajentarta

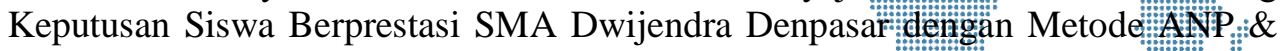
Topsis," J. Inf., vol. 2, no. 2, 2017.

[7] Y. D. Dayati, A. Choiron, and S. Kacung, "Data Warefö Analisa Prestasi Akademik Siswa di SMP Roudlotul Jadid Lumajang," Inf. "J:' Ilm. Bid. Teknol. Inf. dan Komun., vol. 1, no. 1, pp. 59-70, 2016.

[8] E. A. Tukan and J. Kennedy, "Sistem Pendukung Keputusan Prestasi Siswa Menggunakan Metode Topsis," in Seminar Nasional Teknologi Informasi dan Multimedia 2016, 2016, pp. 55-60.

[9] H. Hamid, S. Hady, H. Wijaya, and W. O. Martina, "Penerapan Metode Analytic Hierarchy Process Pada Sistem Pendukung Keputusan Prestasi Akademik Siswa Sekolah Dasar," J. Inform., vol. 9, no. 2, pp. 75-84, 2020.

[10] A. N. Fitriana, Harliana, and Handaru, "Sistem Pendukung Keputusan Untuk Menentukan Prestasi Akademik Siswa dengan Metode TOPSIS," Creat. Inf. Technol. J., vol. 2, no. 2, pp. 153-164, 2015.

[11] Narti, "Pengambilan Keputusan Pemilihan Siswa Berprestasi Menggunakan Metode AHP Dan Topsis," J. Inform., vol. 4, no. 2, pp. 198-205, 2017.

\section{Authors}

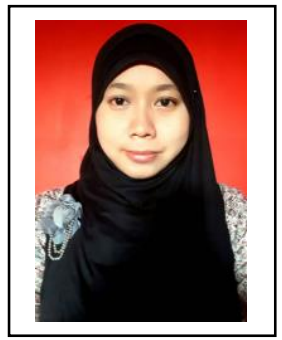

1 st Author

Susliansyah

Lecturer of Universitas Bina Sarana Informatika, Indonesia 